\title{
Review
}

\section{The challenge of surrealism: The correspondence of Theodor W. Adorno and Elisabeth Lenk}

\author{
Susan H. Gillespie (ed) \\ University of Minnesota Press, Minneapolis, 2015, 248pp., \\ ISBN: 978-0-81665617-2
}

Contemporary Political Theory (2017) 16, 405-408. doi:10.1057/s41296-016-0020-z; advance online publication 23 August 2016

In her talk on "Critical Theory and Surreal Practice" Elisabeth Lenk asks, "[w]hether surrealism ... was and is not precisely the practice that is appropriate to critical theory; and whether ... critical theory was and is not precisely the theory toward which surreal practice was oriented" (p. 41). This incisive question provides the framework for thinking about the relationship between the Frankfurt School tradition of critical theory and surrealism in The Challenge of Surrealism: The Correspondence of Theodor W. Adorno and Elisabeth Lenk. In addition to the correspondence, which appears in English for the first time, the volume includes a rich selection of essays that provide additional context for Lenk and Adorno's spirited exchange.

The volume is organized around the correspondence, which lasts from 1962 until Adorno's death in 1969. Lenk was Adorno's graduate student, living in France and writing a dissertation on André Breton's surrealist group in Paris. As an active member of the Students for a Democratic Society (SDS), Lenk was on the front lines of the student movements and met daily with the surrealists until she was expelled for "situationist deviation" in 1967. In addition to the correspondence, there are three essays from Lenk including her talk on "Critical Theory and Surreal Practice," "Sense and Sensibility: Afterword to Louis Aragon's Paris Peasant," and an introduction to Charles Fourier's The Theory of the Four Movements and the General Destinies. The volume also presents fresh translations of Walter Benjamin's "Surrealism: Last Snapshot of the European Intelligentsia" and Adorno's "Surrealism Reconsidered," along with four prose pieces written pseudonymously by Adorno and Carl Dreyfus. The collection begins with a provocative introduction by Rita Bischof, "Departures: Critical Theory and Surrealism." Bischof, Lenk's student and friend, begins by reflecting on recent political movements including the Arab Spring protests and Pussy Riot, arguing

(c) 2016 Macmillan Publishers Ltd. 1470-8914 Contemporary Political Theory Vol. 16, 3, 405-408 www.palgrave.com/journals 
that critical theory must be attuned to contemporary political events. Surrealism, as a linguistic and aesthetic practice, she argues, draws us into the present and is best suited for this kind of work.

Adorno and Benjamin's classic essays on surrealism follow Bischof's introduction. Benjamin's luminous "Surrealism" offers a critical engagement with André Breton's Nadja. As we see in this early work, Benjamin's conception of historical materialism and the dialectical image is strongly influenced by surrealist writings. "Surrealism," Benjamin writes, "can boast an astonishing discovery. It was the first to stumble on the revolutionary energies that manifest in the 'out of date,' in the first iron constructions, the first factory buildings, the earliest photographs, the objects that are beginning to die out..." (p. 20). The images themselves contain a dialectic, which is accessed through the way the subject approaches the object of contemplation. Contra Benjamin, Adorno's "Surrealism Reconsidered" fails to see the disruptive potential of surrealism, reducing it to its methodologies like "automatic writing." According to Adorno “...dialectical images of surrealism are those of a dialectic of subjective freedom in the state of objective unfreedom" (p. 33). In his view, the montages of surrealism are more like stillborn images, incapable of spurring political opposition or revolutionary movement. In this way, as Bischof wryly notes in her introduction, Adorno "clearly misses the point" of surrealism (p. 8).

Lenk's "Critical Theory and Surreal Practice" begins on a somber note, asking what relevance the two movements have today, now that both have been declared dead. Drawing out a number of similarities between critical theory and surrealism, Lenk writes, "If, therefore, there is a strict criterion to which both movements, surrealism and the Frankfurt School, might have adhered it would be this: cognition of the present" (p. 37). At the heart of both "movements" is a desire for liberation and a gesture toward the present moment. She posits that it was ultimately these two movements "that unleashed the May'68 events" (p. 37). The practice of surrealism can "break up the darkness of the present" and make visible thought that observes itself in the act of thinking. In this spirit, the "Frankfurters and the surrealists sought to add a new dimension to the political," and this new dimension is the space in which they are able to think critically and break free from oppressive linguistic forms (p. 49).

The following chapter, Lenk's "Introduction to the Correspondence," begins with a reflective quote from Benjamin, evoking the surreal nature of letter writing: "The letters, as one reads them in order, with only the briefest of intervals, undergo an objective change, out of their own life. They live in another rhythm than when their recipients were living, and they change in other ways as well" (p. 55). There are a number of common themes that emerge through the letters like "the priority of the political" and "the aesthetic dimension." Unfortunately, Adorno does not offer much by way of reply. Despite Lenk's provocations, he fails to engage her invitations to discuss further surrealism or situationism in writing. At one point, 
Lenk sends Adorno a poem of Breton's that she has translated into German, to which Adorno responds he was unable to "strike any real fire from the translation or from the original" (p. 5). Many of the exchanges refer to conversations that were had in person, for which Lenk has provided detailed commentary at the bottom of the letters.

The letters provide insight into Lenk's philosophical and political commitments while letting readers see Adorno's more personable and flirtatious side. Many of the letters deal with technical issues like making arrangements to meet or talk about dissertations chapters, grants, and publishing. But there are two distinct turns in the correspondence. The first occurs when Adorno replies to Lenk's "Thoughts on the Relationship between Sade and Fourier." He shifts from the formal Sie to the informal $d u$, writing, "I have never, really never, met a woman whom I consider to be as endowed with genius as you are." Adorno adds, "Please, don't ascribe that to my feeling of being in love, to which it merely contributes even more." The letter ends with an invitation to steal away together, but Adorno's advance goes unanswered. The second turn occurs after Adorno's friend Benno Ohnesorg's is murdered during the June 2, 1967 protests. And in Letter 71 Adorno describes the student protest actions against him as his "little scandal with the SDS" (p. 163). In an extended note for Letter 83, Lenk offers a timeline to fill in the details of Adorno's letters and position within and against the protests. The correspondence ends with a solemn exchange between Lenk and Gretel Adorno.

Shifting from the correspondence to Lenk's essays "Sense and Sensibility: Afterword to Louis Aragon's Paris Peasant" and preface for Charles Fourier's Four Movements, we are presented with illuminating reflections on Aragon, Benjamin, Marx, and Lukács. In the first, Lenk begins by reflecting on the demise of surrealism, calling it "obsolete" and arguing that its works have become "fetishes" (p. 187). Lenk describes Aragon's intoxicating novel as a relation between "poetic production and philosophical reflection" (p. 187). The interplay between mythology and enlightenment thinking is at play in surrealism, and Lenk attempts to untangle Aragon's understanding of perception from Descartes's desensitized logic. "But perception, as Aragon sees it, is neither simple nor positive; it is surreal perception. The senses think" (p. 188). Lenk discusses the influence of Baudelaire and modernism on Aragon along with the Hegelian definition of nature. In this spirit, Aragon's work plays on the dialectic relation between man and nature, rediscovering the "pagan nature in the metropolis" (p. 189). Paris Peasant, Lenk writes, is an attempt to "show where, in the interstices of the contemporary world, mythical elements reside" (p. 189).

The penultimate essay, Lenk's introduction to The Theory of the Four Movements and the General Destinies, explores Fourier's influence upon surrealism and the foundations of critical theory. In her introduction to the letters she notes, "The path from the political to the aesthetic and back took place, in our correspondence, under the sign of Charles Fourier" (p. 61). At the heart of this path

(c) 2016 Macmillan Publishers Ltd. 1470-8914 Contemporary Political Theory Vol. 16, 3, 405-408 407 
is the question of the passions. Fourier argues that "the passions, as emanations of attraction, are designed to be the seat of autonomy and self-affirmation of human beings," and that social impulses of desire are akin to Hegel's "cunning of reason" (p. 209). Surrealism seeks to break with the past and oppressive forces, and the passions are "meant to play the leading role in the society of the future," lending "rhythm and harmony" to social movements (p. 209). Opposed to forces of enlightenment thinking, the passions are not something to be contained, but rather become a force for liberation. Fourier provides a social theory for the role the passions can play in political emancipation. "In the future," Lenk writes, "the five senses will not be passive instruments that merely register the world but will press forward, actively and critically, in the direction of continuous refinement..." (p. 210). Fourier's system tells us to follow the passions without constraint in order to undermine the extant political and economic institutions, to move toward an absolute understanding of happiness.

The volume ends with Adorno and Dreyfus's pseudo-surrealist writings. In one letter, Adorno tells Lenk that these pieces were meant to express "the feeling one has when climbing a flight of stairs and starts to take another step after already reaching the top" (p. 80). The collection resembles some of Benjamin's fragments in One Way Street, and although there are echoes of surrealism ("Funerary Monument") gesturing toward temporal disjuncture, they ultimately fall flat. The stories sound more like traveling anecdotes or absurd events we tell friends with riotous composure after a couple of drinks.

Gillespie's finely edited volume provides historical context and provocation for the further study of critical theory and surrealism. The correspondence offers readers a different side of Adorno, but the real contribution comes from Lenk's writings about surrealism and her own surreal notes for the letters. Beautifully edited and translated, this book will be of interest to anyone working on surrealism, Adorno, Benjamin, and the Frankfurt School tradition.

Samantha Rose Hill Bard College, Annandale-on-Hudson, New York 12504, USA shill@bard.edu 